Article

\title{
Synthesis, Crystal Structure, and Hirshfeld Surface Analysis of Hexachloroplatinate and Tetraclorouranylate of 3 -Carboxypyridinium-Halogen Bonds and $\pi$-Interactions vs. Hydrogen Bonds
}

\author{
Anton Petrovich Novikov*(D), Mikhail Alexandrovich Volkov, Alexey Vladimirovich Safonov (D) \\ and Mikhail Semenovich Grigoriev (D)
}

check for updates

Citation: Novikov, A.P.; Volkov, M.A.; Safonov, A.V.; Grigoriev, M.S. Synthesis, Crystal Structure, and Hirshfeld Surface Analysis of

Hexachloroplatinate and Tetraclorouranylate of 3-Carboxypyridinium-Halogen Bonds and $\pi$-Interactions vs. Hydrogen Bonds. Crystals 2022, 12, 271. https://doi.org/10.3390/ cryst12020271

Academic Editors: Aleksej Zarkov, Aivaras Kareiva and Loreta Tamasauskaite-Tamasiunaite

Received: 30 January 2022

Accepted: 15 February 2022

Published: 17 February 2022

Publisher's Note: MDPI stays neutral with regard to jurisdictional claims in published maps and institutional affiliations.

Copyright: (C) 2022 by the authors. Licensee MDPI, Basel, Switzerland. This article is an open access article distributed under the terms and conditions of the Creative Commons Attribution (CC BY) license (https:// creativecommons.org/licenses/by/ $4.0 /)$.
Frumkin Institute of Physical Chemistry and Electrochemistry, Russian Academy of Sciences, Leninskii prospect 31-4, 119071 Moscow, Russia; mendeleev93@yandex.ru (M.A.V.); alexeysafonof@gmail.com (A.V.S.); mickgrig@mail.ru (M.S.G.)

* Correspondence: tony.novickoff@yandex.ru

\begin{abstract}
This work aimed to synthesize new platinum and uranium compounds with nicotinic acid. In this article we describe the synthesis of two new anionic complexes $(\mathrm{HNic})_{2}\left[\mathrm{PtCl}_{6}\right]$ and ( $\mathrm{HNic})_{2}\left[\mathrm{UO}_{2} \mathrm{Cl}_{4}\right]$ using wet chemistry methods. The structure of the obtained single crystals was established by single-crystal X-ray diffraction. The Hirshfeld surface analysis of the obtained complexes and their analogue $(\mathrm{HNic})_{2}\left[\mathrm{SiF}_{6}\right]$ was carried out for the analysis of intermolecular interactions. Hydrogen bonds $(\mathrm{H} \cdots \mathrm{Hal} / \mathrm{Hal} \cdots \mathrm{H}$ and $\mathrm{O} \cdots \mathrm{H} / \mathrm{H} \cdots \mathrm{O})$ make the main contribution to intermolecular interactions in all compounds. Other important contacts in cations in all compounds are $\mathrm{H} \cdots \mathrm{H}$, $\mathrm{C} \cdots \mathrm{H} / \mathrm{H} \cdots \mathrm{C}$ and $\mathrm{C} \cdots \mathrm{Hal} / \mathrm{Hal} \cdots \mathrm{C}$; in anions $\mathrm{H} \cdots \mathrm{Hal} / \mathrm{Hal} \cdots \mathrm{H}$. The Pt-containing complex has a halogen- $\pi$ interaction and halogen bonds, but Si-containing complex has a $\pi-\pi$ staking interaction; these types of interactions are not observed in the U-containing compound.
\end{abstract}

Keywords: X-ray diffraction analysis; Hirshfeld surface analysis; nicotinic acid; platinum; uranium; $\pi$-interactions; halogen bonds; hydrogen bonds

\section{Introduction}

The synthesis and investigation of structural features of biomolecular $f$-element compounds are of great fundamental and practical interest in various fields including medicine, radioecology, and toxicology. In our work, we pay attention to niacin, also known as nicotinic acid or vitamin $B_{3}$, which plays a significant role in cellular energy metabolism [1]. Since nicotinic acid contains not only a carboxyl group but also a nitrogenous heterocycle, it has great potential to form compounds with metals using various mechanisms. One of the mechanisms is realized through non-covalent interactions between the metal atom and the nitrogen atom or $\pi$-electron density of the ring [2]. Weak non-covalent interactions are important for the design, operation, and efficiency of molecular sensors and switches [3,4]. These contacts include anion $-\pi$ interaction (including the usual anion $-\pi$, anion $-\pi-$ cation and anion $-\pi-\pi$ interactions) as well as $\pi$-stacking, or cation $-\pi$-interactions. Since interactions of this type provide rapid association-dissociation between molecules, they are of great importance in the formation of biological self-assembling systems and pharmaceuticals [5].

Previous works have noted the role of intermolecular hydrogen bonds (HB) and $\pi-$ $\pi$ interactions in cocrystallization [6] and self-association [7,8] for nicotinic acid and its derivatives. The use of nicotinic acid in organic frameworks with various metals is also based on various non-valent interactions $[9,10]$. Tetranuclear and hexanuclear platinumcontaining metallacycles based on non-covalent interactions are known [11]. Nicotinic 
acid metal complexes show various biological activities (antimicrobial, anti-inflammatory, analgesic, anti-tubercular, anticancer, etc.) [12].

Organic platinum compounds (dichlorodiammineplatinum, diammineplatinum, etc.) are used as cytostatics in the treatment of various forms of cancer [13,14]. Currently, a search is underway for new platinum compounds for use in medicine, including the use of nicotinic acid $[15,16]$.

The coordination chemistry of $f$-elements, especially their halogen derivatives, makes it possible to form many intermolecular interactions. This opens up a large range of functionalities for such compounds. In [4], the platinum complexes [( $\left.\left(\mathrm{Bu}_{2} \mathrm{bpy}\right) \mathrm{Pt}(\mathrm{C} \equiv \mathrm{CAr})_{2}\right]$ $\left(\mathrm{tBu}_{2}\right.$ bpy $=4,4^{\prime}$-bis-tert-butyl-2,2'-bipyridine, $\mathrm{Ar}=4$-pyridyl, 1; 3-pyridyl, 2; 2-pyridyl, 3; 4-ethynylpyridyl, 4; 2-thienyl, 5; pentafluorophenyl, 6) were synthesized and the following types of interactions have been described: $\mathrm{C}-\mathrm{H} \cdots \pi(\mathrm{C} \equiv \mathrm{C}), \mathrm{C}-\mathrm{H} \cdots \mathrm{N}(\mathrm{py}), \mathrm{Cl} \cdots \mathrm{Cl}$, and $\mathrm{C}-\mathrm{H} \cdots \mathrm{F}-\mathrm{C}$.

The study of uranium compounds with biomolecules is important in toxicology for detecting their toxic effects in cells [17]. In radioecology, the study of various uranium compounds with biologically active molecules is important for assessing possible mechanisms of uranium immobilization in the environment in plants, algae, fungi, and microorganisms. Previously, we have shown the effect of uranium immobilization due to carbonyl groups of o-polysaccharide bacteria living in uranium-contaminated groundwater [18]. In [19], uranium complexes with nicotinic acid in solutions were observed, and their formation constants were determined. The formation of uranium complexes with nicotinic acid has also been shown in [20].

Numerous works have noted the ability of uranium-containing compounds to participate in intermolecular interactions [21-24]. Thus, the complexes of uranyl cation with 4-halopyridinium ions ( $\mathrm{Hal}=\mathrm{Cl}, \mathrm{Br}$, I) can be divided into two categories based on the different modes of hydrogen bonding and halogen-halogen interactions present in the crystal structures [25].

Besides its involvement in nuclear energy, organic complexes of uranium are used in photoluminescence [26], magnetism [27], and catalytic [28,29].

In the major part of known $\mathrm{Pt}$ and $\mathrm{U}$ compounds with nicotinic acid, this acid enters into the coordination sphere of central atoms to form $\mathrm{M}-\mathrm{N}$ or $\mathrm{M}-\mathrm{O}$ coordination bonds. Thus, we aimed to obtain compounds of $\mathrm{Pt}(\mathrm{IV})$ and $\mathrm{U}(\mathrm{VI})$ with nicotinic acid in cationic form and to describe the crystal structure and intermolecular interactions.

\section{Materials and Methods}

\subsection{Materials}

Complexes 1 and 2 were synthesized using hexachloroplatinic (IV) acid hexahydrate $\left(\mathrm{H}_{2} \mathrm{PtCl}_{6} \times 6 \mathrm{H}_{2} \mathrm{O}, \sim 40 \% \mathrm{Pt}\right)$, hydrochloric acid $(\mathrm{HCl}, 12.5 \mathrm{M})$, and nicotinic acid $\left(\mathrm{C}_{6} \mathrm{H}_{5} \mathrm{NO}_{2}\right.$ $>98 \%$ ) all being ACS reagent grade chemicals purchased from Sigma-Aldrich (St. Louis, Missouri, United States) and used without additional purification. Uranyl acetate dihydrate $\left(\mathrm{UO}_{2}\left(\mathrm{CH}_{3} \mathrm{COO}\right)_{2} \times 2 \mathrm{H}_{2} \mathrm{O}>99 \%\right.$ ) was purchased from PA "IZOTOP". (Moscow, Russia) To prepare the solutions, twice-distilled water was used, whose electric resistance was not less than $18 \mathrm{MOhm} \mathrm{cm}$.

\subsection{Synthesis of Complexes bis(3-pyridinecarboxylic Acid) Hexachloroplatinate, $\left(\mathrm{HNic}_{2}\left[\mathrm{PtCl}_{6}\right]\right.$ (I)}

In a $10 \mathrm{~mL}$ two-neck flask equipped with a thermometer and a reflux condenser, $10 \mathrm{mg}$ of nicotinic acid was dissolved in $5 \mathrm{~mL}$ of $0.1 \mathrm{M} \mathrm{HCl}$ at room temperature. After dissolving all the nicotinic acid, $0.1 \mathrm{~mL}$ of an aqueous solution of $0.7 \mathrm{~mol} / \mathrm{L}$ platinic acid was added to the flask. The mixture was stirred for $5 \mathrm{~min}$ at room temperature, then the temperature was raised to $70^{\circ} \mathrm{C}$ and held for $15 \mathrm{~min}$. The resulting solution was cooled to room temperature without stopping stirring the flask, then removed the return condenser and thermometer; the flask with the solution was transferred to a vacuum desiccator and left for $12 \mathrm{~h}$ over anhydrous $\mathrm{Mg}\left(\mathrm{ClO}_{4}\right)_{2}$. The resulting yellow needles were washed with two $5 \mathrm{~mL}$ portions 
of cold methanol and dried in an oil pump vacuum at room temperature. The yield was $81 \%$ for nicotinic acid. $(\mathrm{Mr}=654 \mathrm{~g} / \mathrm{mol})$.

2.3. Synthesis of Complexes bis(3-pyridinecarboxylic Acid) Uranile Tetrachloride, $\left(\mathrm{HNic}_{2}\left[\mathrm{UO}_{2} \mathrm{Cl}_{4}\right]\right.$ (II)

In a $10 \mathrm{~mL}$ two-necked flask equipped with a thermometer and a reflux condenser, $10 \mathrm{mg}$ of nicotinic acid was dissolved in $2 \mathrm{~mL}$ of $0.1 \mathrm{M} \mathrm{HCl}$. After dissolving all the nicotinic acid, $3 \mathrm{ml}$ of a $0.01 \mathrm{M}$ solution of uranyl acetate in $0.1 \mathrm{M} \mathrm{HCl}$ was added. The solution was stirred at room temperature for $5 \mathrm{~min}$, then the mixture's temperature was gradually raised to $70^{\circ} \mathrm{C}$ and held for $10 \mathrm{~min}$. The resulting solution was cooled to room temperature without stopping stirring the flask, then removed the return condenser and thermometer; the flask with the solution was transferred to a vacuum desiccator and left for $12 \mathrm{~h}$ over anhydrous $\mathrm{Mg}\left(\mathrm{ClO}_{4}\right)_{2}$. The resulting yellow fluorescent crystals were washed with $5 \mathrm{~mL}$ of cold methanol and dried in vacuo at room temperature. The yield was $97 \%$ for nicotinic acid.

The precipitate I obtained was characterized by X-ray powder diffraction analysis; the diffraction pattern (Figure S1) was in a good agreement with the theoretical one and does not contain peaks corresponding to the starting substances. For compound II, the amount of the precipitate was insufficient for X-ray powder analysis. Some good crystals were selected for single-crystal X-ray diffraction studies.

\subsection{Powder XRD Analysis}

X-ray phase analysis was performed on a PANalytical AERIS diffractometer (Malvern, Worcestershire, United Kingdom; Almelo, Netherlands) with a $\mathrm{Cu}$ anode $(40 \mathrm{kV})$. The analysis was performed over a 28 angle range from 3 to $70^{\circ}$.

\subsection{Single-Crystal XRD Analysis}

The crystal structure of all synthesized substances was determined by X-ray structural analysis using an automatic four-circle area-detector diffractometer Bruker KAPPA APEX II (Billerica, MA, USA) with MoK $\alpha$ radiation at a temperature of 100 and $296 \mathrm{~K}$ (for I) and $100 \mathrm{~K}$ (for II). The cell parameters were refined over the entire data set and data reduction by using SAINT-Plus software [30]. Absorption corrections were introduced using the SADABS program [31]. The structures were solved directly with the SHELXS97 [32] and refined by SHELXL-2018/3 [33]. The N- and C-bound hydrogen atoms were placed at calculated positions. The $\mathrm{O}$-bound $\mathrm{H}$ atoms were located from different Fourier maps and refined with fixed isotropic displacement parameters $\left[U_{\mathrm{iso}}(\mathrm{H})=1.2 U_{\mathrm{eq}}(\mathrm{O})\right]$. The hydrogen atoms of the $\mathrm{OH}$ groups in I were disordered over two positions with occupancies close to 0.5 (in final refinement, the occupancies were fixed at 0.5 at both temperatures). Tables and pictures for structures were generated by Olex2 [34].

Crystal data, data collection, and structure refinement details are summarized in Table 1. All other crystallographic parameters of structures I and II are indicated in Tables S1-S10. The atomic coordinates were deposited at the Cambridge Crystallographic Data Centre [35], CCDC № 2145387-2145389 for I at 296 K, at $100 \mathrm{~K}$, and II, respectively. The Supplementary crystallographic data can be obtained free of charge from the Cambridge Crystallographic Data Centre via www.ccdc.cam.ac.uk/data_request/cif (accessed on 30 January 2022). 
Table 1. Crystal data and structure refinement for structures I and II.

\begin{tabular}{|c|c|c|c|}
\hline & & & II \\
\hline Empirical formula & $\mathrm{C}_{12} \mathrm{H}_{12} \mathrm{~N}_{2} \mathrm{O}_{4} \mathrm{Cl}_{6} \mathrm{Pt}$ & $\mathrm{C}_{12} \mathrm{H}_{12} \mathrm{~N}_{2} \mathrm{O}_{4} \mathrm{Cl}_{6} \mathrm{Pt}$ & $\mathrm{C}_{12} \mathrm{H}_{12} \mathrm{~N}_{2} \mathrm{O}_{6} \mathrm{Cl}_{4} \mathrm{U}$ \\
\hline Formula weight & 656.03 & 656.03 & 660.07 \\
\hline Temperature/K & $296(2)$ & $100(2)$ & $100(2)$ \\
\hline Crystal system & monoclinic & monoclinic & monoclinic \\
\hline Space group & $P 2_{1} / n$ & $P 2_{1} / n$ & $P 2_{1} / n$ \\
\hline $\mathrm{a} / \AA$ & $9.0534(3)$ & $8.9552(14)$ & $6.6653(2)$ \\
\hline $\mathrm{b} / \AA$ & $9.4852(3)$ & $9.4270(16)$ & $18.4856(5)$ \\
\hline $\mathrm{c} / \AA$ & 11.9423(3) & $11.8579(19)$ & $7.4266(2)$ \\
\hline$\alpha /^{\circ}$ & 90 & 90 & 90 \\
\hline$\beta /{ }^{\circ}$ & $110.521(1)$ & $110.400(8)$ & $95.0330(10)$ \\
\hline$\gamma /{ }^{\circ}$ & 90 & 90 & 90 \\
\hline Volume $/ \AA^{3}$ & $960.45(5)$ & $938.3(3)$ & $911.52(4)$ \\
\hline Z & 2 & 2 & 2 \\
\hline$Z^{\prime}$ & 0.5 & 0.5 & 0.5 \\
\hline$\rho_{\text {calc }} \mathrm{g} / \mathrm{cm}^{3}$ & 2.268 & 2.322 & 2.405 \\
\hline$\mu / \mathrm{mm}^{-1}$ & 8.159 & 8.352 & 9.521 \\
\hline $\mathrm{F}(000)$ & 620.0 & 620.0 & 612.0 \\
\hline Crystal size $/ \mathrm{mm}^{3}$ & $0.2 \times 0.18 \times 0.1$ & $0.32 \times 0.12 \times 0.1$ & $0.16 \times 0.14 \times 0.06$ \\
\hline Radiation & $\operatorname{MoK} \alpha(\lambda=0.71073)$ & $\operatorname{MoK} \alpha(\lambda=0.71073)$ & $\operatorname{MoK} \alpha(\lambda=0.71073)$ \\
\hline $2 \Theta$ range for data collection $/{ }^{\circ}$ & 8.194 to 59.998 & 8.44 to 59.988 & 8.182 to 70 \\
\hline Index ranges & $\begin{array}{c}-11 \leq \mathrm{h} \leq 12,-12 \leq \mathrm{k} \leq 13 \\
-16 \leq 1 \leq 16\end{array}$ & $\begin{array}{c}-12 \leq \mathrm{h} \leq 12,-13 \leq \mathrm{k} \leq 13 \\
-16 \leq 1 \leq 16\end{array}$ & $\begin{array}{c}-8 \leq \mathrm{h} \leq 10,-29 \leq \mathrm{k} \leq 29 \\
-11 \leq 1 \leq 11\end{array}$ \\
\hline Reflections collected & $10,00 \overline{6}$ & $1 \overline{4}, 37 \overline{7}$ & $1 \overline{8}, 01 \overline{0}$ \\
\hline Independent reflections & $\begin{array}{c}2794\left[R_{\text {int }}=0.0205,\right. \\
\left.R_{\text {sigma }}=0.0201\right]\end{array}$ & $\begin{array}{c}2735\left[R_{\text {int }}=0.0559\right. \\
\left.R_{\text {sigma }}=0.0416\right]\end{array}$ & $\begin{array}{c}4002\left[R_{\text {int }}=0.0283,\right. \\
\left.R_{\text {sigma }}=0.0253\right]\end{array}$ \\
\hline Data/restraints/parameters & $2794 / 2 / 122$ & $2735 / 2 / 121$ & $4002 / 0 / 115$ \\
\hline Goodness-of-fit on $\mathrm{F}^{2}$ & 1.048 & 1.030 & 1.284 \\
\hline Final $\mathrm{R}$ indexes $[\mathrm{I}>=2 \sigma(\mathrm{I})]$ & $\mathrm{R}_{1}=0.0160, \mathrm{wR}_{2}=0.0372$ & $\mathrm{R}_{1}=0.0235, \mathrm{w} \mathrm{R}_{2}=0.0529$ & $\mathrm{R}_{1}=0.0310, \mathrm{w} \mathrm{R}_{2}=0.0546$ \\
\hline Final $\mathrm{R}$ indexes [all data] & $\mathrm{R}_{1}=0.0234, \mathrm{w} \mathrm{R}_{2}=0.0404$ & $\mathrm{R}_{1}=0.0323, \mathrm{w} \mathrm{R}_{2}=0.0568$ & $\mathrm{R}_{1}=0.0398, \mathrm{wR}_{2}=0.0562$ \\
\hline Largest diff. peak/hole/e $\AA^{-3}$ & $0.78 /-0.69$ & $0.82 /-1.21$ & $1.47 /-2.32$ \\
\hline
\end{tabular}

\section{Results and Discussion}

\subsection{Structural Description}

Both compounds crystallize in the space group $P 2_{1} / n$ with two formula units in the unit cell. The asymmetric units are illustrated in Figure 1. Platinum and uranium atoms are in special positions two $a$ and $2 b$, respectively. In both compounds, the platinum and uranium atoms are octahedrally coordinated. $\mathrm{Pt}-\mathrm{Cl}$ distances are changed from $2.3090(8)$ $\AA$ to $2.3180(8) \AA$ in $\mathbf{I}$ at $100 \mathrm{~K}$, and the average distance is $2.313 \AA$, which can be seen from Table 2. With the increase in temperature to $296 \mathrm{~K}$, this distance slightly increases and amounts to $2.317 \AA$. At both temperatures, the $\mathrm{Cl}-\mathrm{Pt}-\mathrm{Cl}$ angles in I are close to $90^{\circ}$ (Table 2).

Table 2. Selected geometric parameters $\left(\AA,^{\circ}\right)$ for $\mathbf{I}$.

\begin{tabular}{|c|c|c|c|c|c|}
\hline \multicolumn{4}{|c|}{$100 \mathrm{~K}$} & \multicolumn{2}{|c|}{$296 \mathrm{~K}$} \\
\hline $\mathrm{Pt} 1-\mathrm{Cl1}$ & $2.3180(8)$ & $\mathrm{Cl} 2-\mathrm{Pt} 1-\mathrm{Cl} 3$ & $90.89(3)$ & $\mathrm{Pt} 1-\mathrm{Cl1}$ & $2.3220(6)$ \\
\hline $\mathrm{Pt} 1-\mathrm{Cl} 2$ & $2.3090(8)$ & $\mathrm{Cl} 2-\mathrm{Pt} 1-\mathrm{Cl} 1$ & $89.06(3)$ & $\mathrm{Pt} 1-\mathrm{Cl} 3$ & $2.3139(5)$ \\
\hline $\mathrm{Pt} 1-\mathrm{Cl3}$ & $2.3107(8)$ & $\mathrm{Cl} 3-\mathrm{Pt} 1-\mathrm{Cl} 1$ & $90.43(3)$ & $\mathrm{Pt} 1-\mathrm{Cl} 2$ & $2.3144(5)$ \\
\hline
\end{tabular}



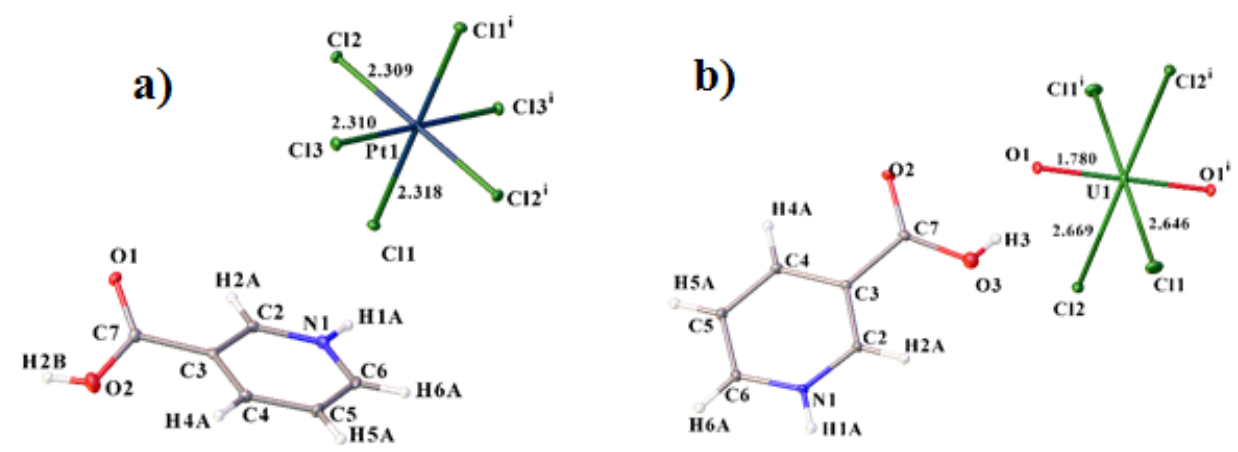

Figure 1. Molecular structure of I (a) and II (b) at $100 \mathrm{~K}$, including atom labeling. Only one position of the disordered H-atom of the carboxyl group is shown in I. Displacement ellipsoids are drawn at the $50 \%$ probability level.

Uranyl tetrachloride forms a bipyramid. The average $\mathrm{U}-\mathrm{Cl}$ distance in II is $2.658 \AA$, which is slightly shorter than in previous works in the CSD, where it was $2.67 \AA$. The $\mathrm{U}-\mathrm{O}$ distance is 1.780(2) $\AA$, which is longer than the average distance at $100 \mathrm{~K}$ in CSD, where it was $1.772 \AA$. This may be due to the participation of the oxygen atom of the anion in $\mathrm{H}$-bonds. The angles $\mathrm{Cl}-\mathrm{U}-\mathrm{Cl}$ and $\mathrm{O}-\mathrm{U}-\mathrm{Cl}$ are close to $90^{\circ}$, as shown in Table 3 . The position of the protonated oxygen atom in I and II is different relative to the nitrogen atom of the six-membered ring (torsion angles C4-C3-C7-O2(3) are $-28.85^{\circ}$ in I and $-162.50^{\circ}$ in II).

Table 3. Selected geometric parameters $\left(\AA^{\circ},{ }^{\circ}\right)$ for II.

\begin{tabular}{cccc}
\hline $\mathrm{U} 1-\mathrm{O} 1$ & $\mathbf{1 . 7 8 0}(2)$ & O1-U1-Cl1 & $\mathbf{8 9 . 8 1 ( 8 )}$ \\
\hline $\mathrm{U} 1-\mathrm{Cl1}$ & $2.6461(8)$ & $\mathrm{O} 1-\mathrm{U} 1-\mathrm{Cl}$ & $89.86(8)$ \\
$\mathrm{U} 1-\mathrm{Cl} 2$ & $2.6694(7)$ & $\mathrm{O} 1-\mathrm{U} 1-\mathrm{Cl1}$ & $89.81(8)$ \\
\hline
\end{tabular}

The hydrogen bond system of $\mathbf{I}$ is shown in Figure 2a. In I, one bifurcate hydrogen bond $\mathrm{O} 2-\mathrm{H} 2 \mathrm{~B} \cdots \mathrm{Cl} 1^{\mathrm{i}}$ and $\mathrm{O} 2-\mathrm{H} 2 \mathrm{~B} \cdots \mathrm{Cl}^{\mathrm{i}}$ [symmetry code: (i) $-x+1,-y+1,-z+2$ ] is formed (Table 4). The strongest hydrogen bond is formed by N1-H1A with O1iii of another cation with an $\mathrm{N} \cdots \mathrm{O}$ distance of $2.728(4) \AA$ [symmetry code: (iii) $x-1 / 2,-y+3 / 2, z-1 / 2$ ]. In II, one bifurcate hydrogen bond is also formed (Figure $2 \mathrm{~b}$ ). N1 - H1A forms a bifurcate H-bond with $\mathrm{Cl}^{\mathrm{i}}$ and $\mathrm{O}^{\mathrm{ii}}$ [symmetry codes: (i) $x+1, y, z+1$; (ii) $x, y, z+1$ ]. In both compounds, the $\mathrm{CH}$ groups of the six-membered rings form weak $\mathrm{H}$-bonds of the $\mathrm{C}-\mathrm{H} \cdots \mathrm{Cl}$ type, which provide additional bonding of cations and anions in the compounds, such as in [36,37]. In I, only one $\mathrm{C}-\mathrm{H} \cdots \mathrm{Cl}$ bond is formed, in II three (Table 5), but two of them in II are weaker than in $\mathbf{I}$.

Table 4. Hydrogen-bond geometry for I at $100 \mathrm{~K}\left(\AA{ }^{\circ}{ }^{\circ}\right)$.

\begin{tabular}{lllll}
\hline $\mathbf{D}-\mathbf{H} \cdots \mathbf{A}$ & $\mathbf{D}-\mathbf{H}$ & $\mathbf{H} \cdots \mathbf{A}$ & $\mathbf{D} \cdots \mathbf{A}$ & $\mathbf{D}-\mathbf{H} \cdots \mathbf{A}$ \\
\hline $\mathrm{O} 2-\mathrm{H} 2 \mathrm{~B} \cdots \mathrm{Cl} 1^{\text {i }}$ & $0.85(2)$ & $2.70(5)$ & $3.486(3)$ & $155(10)$ \\
$\mathrm{O} 2-\mathrm{H} 2 \mathrm{~B} \cdots \mathrm{Cl} 3^{\text {i }}$ & $0.85(2)$ & $2.79(8)$ & $3.401(3)$ & $131(9)$ \\
$\mathrm{O} 2-\mathrm{H} 2 \mathrm{C} \cdots \mathrm{Cl} 3^{\text {ii }}$ & $0.86(2)$ & $2.61(4)$ & $3.413(3)$ & $155(8)$ \\
$\mathrm{N} 1-\mathrm{H} 1 \mathrm{~A} \cdots \mathrm{O} 1^{\text {iii }}$ & 0.88 & 1.87 & $2.728(4)$ & 163.0 \\
$\mathrm{C} 2-\mathrm{H} 2 \mathrm{~A} \cdots \mathrm{Cl} 1^{\text {iv }}$ & 0.95 & 2.66 & $3.500(3)$ & 148.0 \\
\hline
\end{tabular}

Symmetry codes: (i) $-\mathrm{x}+1,-\mathrm{y}+1,-\mathrm{z}+2$; (ii) $\mathrm{x}-1 / 2,-\mathrm{y}+1 / 2, \mathrm{z}+1 / 2$; (iii) $\mathrm{x}-1 / 2,-\mathrm{y}+3 / 2, \mathrm{z}-1 / 2$; (iv) $-\mathrm{x}+1 / 2$, $\mathrm{y}+1 / 2,-\mathrm{z}+3 / 2$. 

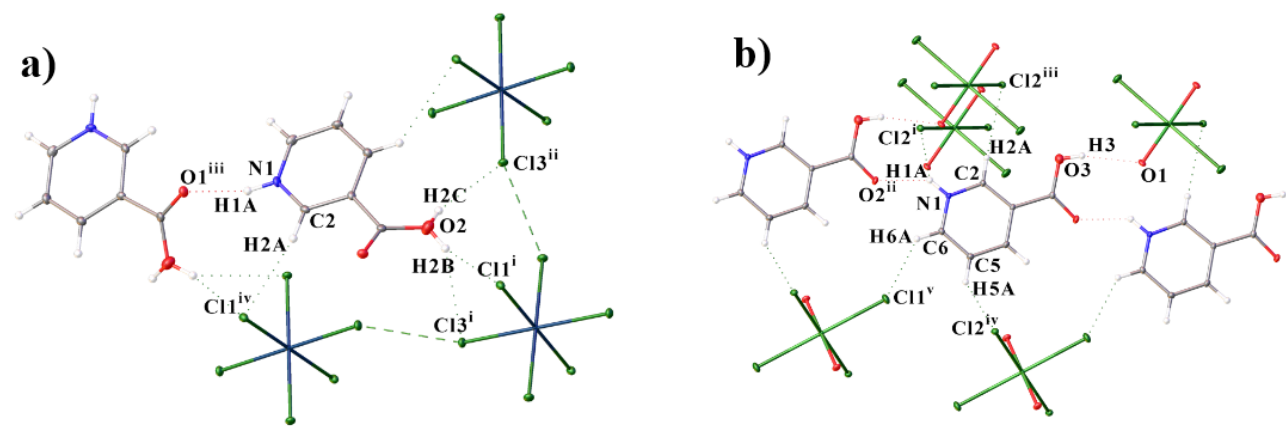

Figure 2. View showing the hydrogen and halogen bonds in I (a) [Symmetry codes: (i) $-x+1,-y+1$, $-z+2$; (ii) $x-1 / 2,-y+1 / 2, z+1 / 2$; (iii) $x-1 / 2,-y+3 / 2, z-1 / 2$; (iv) $3 / 2-x, 1 / 2+y, 3 / 2-z$.] and hydrogen bonds in II (b) [Symmetry codes: (i) $x+1, y, z+1$; (ii) $x, y, z+1$ ]. Both positions of the disordered hydrogen atom of carboxyl group in $\mathbf{I}$ are shown.

Table 5. Hydrogen-bond geometry for II $\left(\AA{ }^{\circ}{ }^{\circ}\right)$.

\begin{tabular}{lllll}
\hline $\mathbf{D}-\mathbf{H} \cdots \mathbf{A}$ & $\mathbf{D}-\mathbf{H}$ & $\mathbf{H} \cdots \mathbf{A}$ & $\mathbf{D} \cdots \mathbf{A}$ & $\mathbf{D}-\mathbf{H} \cdots \mathbf{A}$ \\
\hline $\mathrm{O} 3-\mathrm{H} 3 \cdots \mathrm{O} 1$ & $0.857(3)$ & $2.287(2)$ & $3.125(3)$ & $165.7(2)$ \\
$\mathrm{N} 1-\mathrm{H} 1 \mathrm{~A} \cdots \mathrm{Cl} 2^{\text {i }}$ & 0.88 & 2.81 & $3.380(3)$ & 123.9 \\
$\mathrm{~N} 1-\mathrm{H} 1 \mathrm{~A} \cdots \mathrm{O} 2^{\text {ii }}$ & 0.88 & 2.00 & $2.721(3)$ & 138.3 \\
$\mathrm{C} 2-\mathrm{H} 2 \mathrm{~A} \cdots \mathrm{Cl} 2^{\text {iii }}$ & 0.95 & 2.69 & $3.611(3)$ & 163.4 \\
$\mathrm{C} 5-\mathrm{H} 5 \mathrm{~A} \cdots \mathrm{Cl} 2^{\text {iv }}$ & 0.95 & 2.82 & $3.543(3)$ & 133.8 \\
$\mathrm{C} 6-\mathrm{H} 6 \mathrm{~A} \cdots \mathrm{Cl}{ }^{\mathrm{v}}$ & 0.95 & 2.67 & $3.411(3)$ & 135.4 \\
\hline
\end{tabular}

Symmetry codes: (i) $\mathrm{x}+1, \mathrm{y}, \mathrm{z}+1$; (ii) $\mathrm{x}, \mathrm{y}, \mathrm{z}+1$; (iii) $-\mathrm{x}+1,-\mathrm{y}+1,-\mathrm{z}+1$; (iv) $\mathrm{x}+1 / 2,-\mathrm{y}+3 / 2, \mathrm{z}+1 / 2$; (v) $-\mathrm{x}+3 / 2$, $\mathrm{y}+1 / 2,-\mathrm{z}+3 / 2$.

The crystal packing in I can be represented as cationic and anionic layers parallel to the plane (-101) (Figure 3a). The cations in the layers are linked by hydrogen bonds of the $\mathrm{N}-\mathrm{H} \cdots \mathrm{O}$ type and are connected to the anionic layers by hydrogen bonds of the $\mathrm{O}-\mathrm{H} \cdots \mathrm{Cl}$ type. Anions in $\mathrm{I}$ are interconnected by halogen bonds $\mathrm{Cl} 2 \cdots \mathrm{Cl}^{\mathrm{v}}$ with a distance of 3.2074(12) A [symmetry code: (v) 3/2-x, 1/2+y, 3/2-z], as in [38]. The crystal packing in II can also consist of cationic and anionic layers parallel to the plane (010). In this case, cations interact with anions and other cations, but anions do not interact, unlike in I.
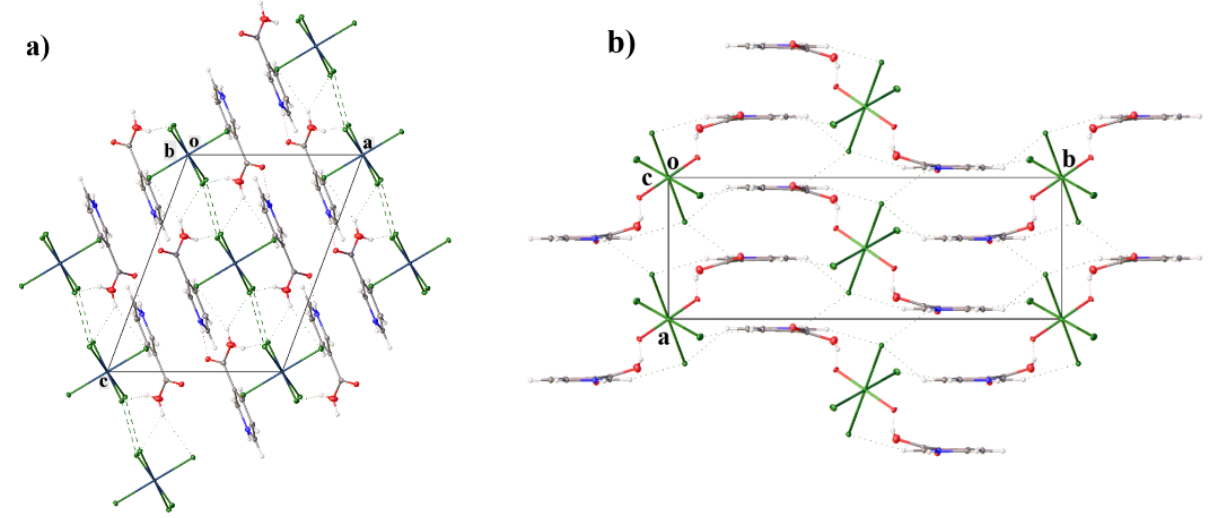

Figure 3. Crystal packing of I (a), showing the layers parallel to the plane (-101) with hydrogen and halogen bonds between them, and II (b), showing the layers parallel to plane (010) with hydrogen bonds between them.

In the earlier research works only one compound of singly protonated nicotinic acid with an octahedral anion was found, bis(3-carboxypyridinium) hexafluorosilicate (III) [39]. In [39], hexafluorosilicate was also added to nicotinic acid by hydrogen bonds. Compound III, like ours, crystallizes in $P 2_{1} / n$ sp. gr. However, other layers are formed in III, in 
which the anions do not interact with each other and in which there are no halogen bonds. However, in III, layers are stabilized due to the presence of $\pi$-stacking interaction between the rings, which is absent in I and II.

It has been established from the literature data that, upon interaction with nicotinic acid, platinum usually participates in $\mathrm{Pt}-\mathrm{N}$ bonds and is attached directly to the nitrogen atom of the six-membered ring, as in $[40,41]$. Only one uranium-containing compound with nicotinic acid is known [42].

\subsection{Hirshfeld Surface Analysis}

Hirshfeld surface (HS) analysis was proposed as a new means of separating space in molecular crystals. The Hirshfeld surface covers the molecule and determines the volume of space in which the electron density of the promolecule exceeds the density of all neighboring molecules [43]. Fingerprint plots are a convenient way of summarizing the intermolecular contacts present in crystals, decomposing this fingerprint plot into features to identify specific interactions. This method can be used to analyze $\pi-\pi$ stacking interactions [44], halogen and hydrogen bonds [45,46], and other weak non-covalent interactions $[47,48]$.

The Crystal Explorer 21 [49] program was used to analyze the crystal and Hirshfeld surface analysis interactions. The donor-acceptor groups are visualized using a standard (high) surface resolution and $d_{\text {norm }}$ surfaces, as illustrated in Figure 4 . Red spots on the surface of the $d_{\text {norm }}$ plot indicate intermolecular contacts involving the hydrogen and halogen bonds. The brightest red spots correspond to the strongest hydrogen bond $\mathrm{N}-$ $\mathrm{H}$... $\mathrm{O}$ in both compounds and $\mathrm{O}-\mathrm{H} \cdots \mathrm{O}$ in II (Figure 4). Weaker red spots correspond to bonds $\mathrm{O}-\mathrm{H} \cdots \mathrm{Cl}$ in $\mathrm{I}$ and $\mathrm{C}-\mathrm{H} \cdots \mathrm{Cl}$ for cations in both compounds. For the anion, red spots on the surface $d_{\text {norm }}$ correspond to hydrogen bonds in I and II, and halogen bonds in I.
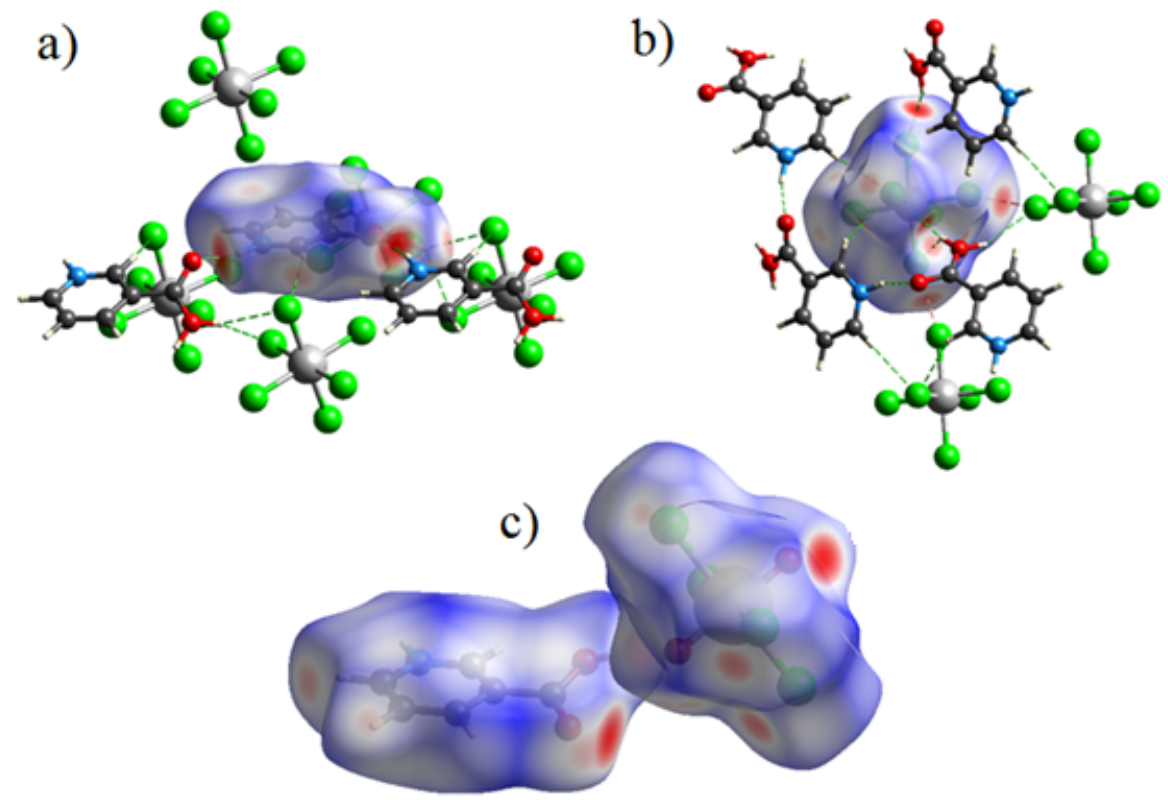

Figure 4. Hirshfeld surface mapper over $d_{\text {norm }}$ for (a) cation and (b) for anion to visualize the interactions in compound I and in II (c).

$\pi$-stacking interactions are absent in I and II, which can be seen from the absence of characteristic red and blue triangles on the shape-index surface (Figure 5). 


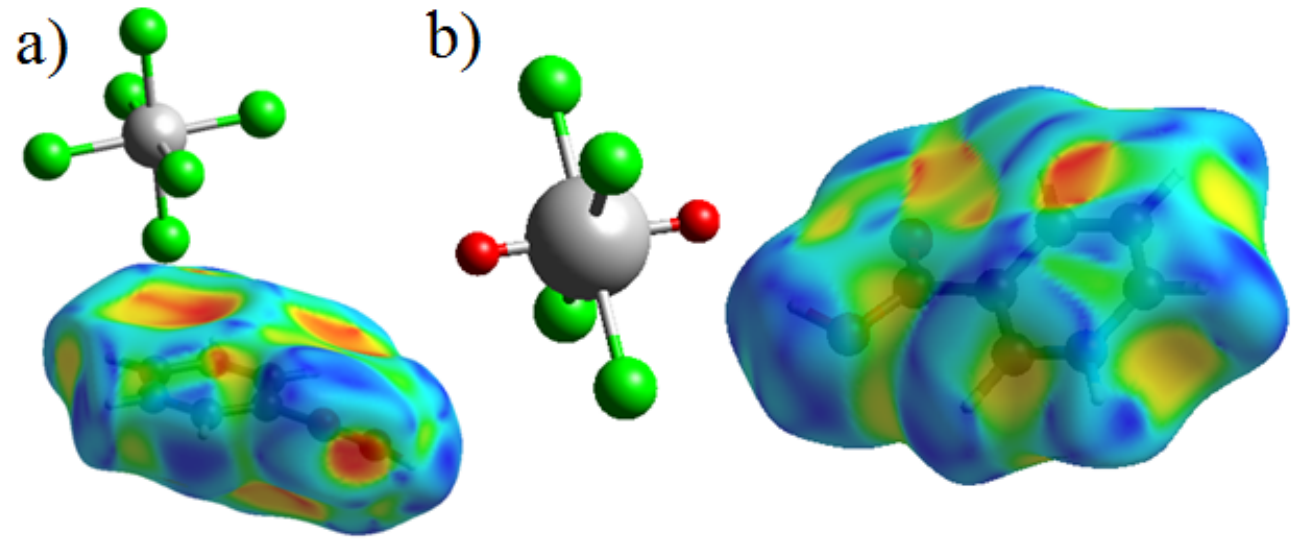

Figure 5. Hirshfeld surface mapper shape-index of cation in I (a) and II (b).

On the Hirschfeld surface $d_{\text {norm }}$ above the six-membered ring, a weak red spot corresponds to the $\mathrm{C} \cdots \mathrm{Cl}$ interaction, which is also seen from the bright red spot on the shape index surface. The C6 $\cdots \mathrm{Cl}$ distance in $\mathrm{I}$ is $3.299 \AA$, which is shorter than the sum of the van der Waals radii of $\mathrm{C}$ and $\mathrm{Cl}$. The distance between the center of the ring and the chlorine atom Cl1 in I at $100 \mathrm{~K}$ is $3.431 \AA$ (3.489 $\AA$ at $296 \mathrm{~K}$ ), and the angle $\alpha$ (Figure 6) is $70.97^{\circ}\left(70.92^{\circ}\right.$ at $\left.296 \mathrm{~K}\right)$. This contact can be called an anion- $\pi$ interaction since the distance between the center of the ring and the anion is less than $5 \AA$, and the angle $\alpha$ is greater than $50^{\circ}[3,50,51]$.

a)

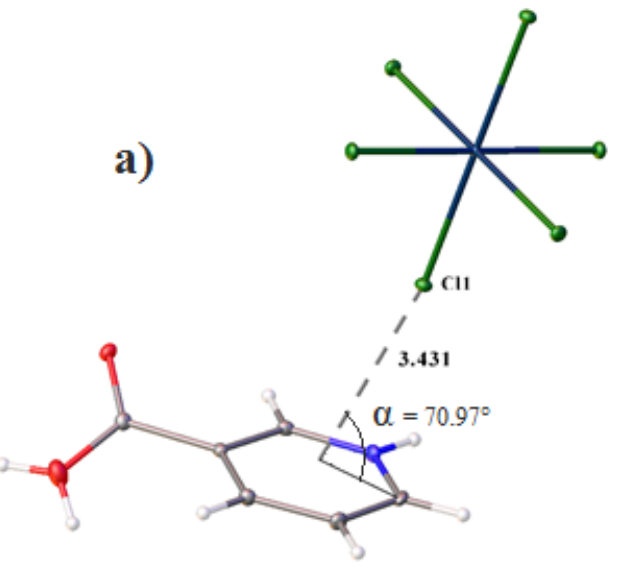

b)

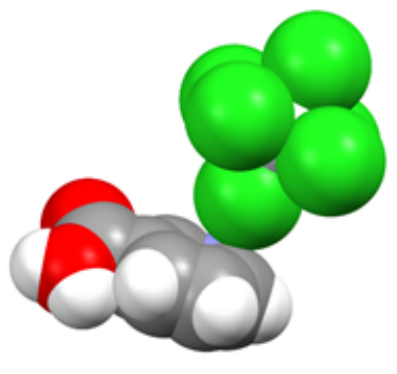

Figure 6. View showing halogen- $\pi$ interactions in the structure I at $100 \mathrm{~K}$ (a) and "spacefill" image (b).

Since there are analogies with $(\mathrm{HNic})_{2}\left[\mathrm{SiF}_{6}\right]$, the Hirschfeld surfaces were also constructed and compared for this derivative of the nicotinium cation. Fingerprint plots for compounds I-III are shown in Figures S1-S6 and can be used to highlight specific short interactions. Separately, 2D branchings for cations and anions were built. It should be noted that the shape of fingerprint graphs for different types of contacts in compounds I-III is different. For example, the $\mathrm{O} \cdots \mathrm{H} / \mathrm{H} \cdots \mathrm{O}$ hydrogen bonds, although there are two elongated peaks in I and II, they are sharper in I than in II, and in III they look like something in between. In this case, all contacts occupy approximately the same position on the fingerprint plots. The different anionic geometry can explain the different shapes of the fingerprint graphs in the compounds and the substitution of chlorine atoms by other atoms.

The temperature changes do not introduce significant changes in the percentage contribution of each type of contacts in cation $\mathbf{I}$, as shown in Figure 7. In all compounds in cations, the main contribution to intermolecular interactions is made by hydrogen bonds (contacts $\mathrm{H} \cdots \mathrm{Hal} / \mathrm{Hal} \cdots \mathrm{H}$ and $\mathrm{O} \cdots \mathrm{H} / \mathrm{H} \cdots \mathrm{O}$ ). The van der Waals interactions $\mathrm{H} \cdots \mathrm{H}$ and $\mathrm{C} \cdots \mathrm{H} / \mathrm{H} \cdots \mathrm{C}$ also play an essential role in the cations of all compounds. The total contribution of hydrogen bonds of the type $\mathrm{H} \cdots \mathrm{Hal} / \mathrm{Hal} \cdots \mathrm{H}$ and $\mathrm{O} \cdots \mathrm{H} / \mathrm{H} \cdots \mathrm{O}$ in cations 
in I and II is the same and is approximately $50 \%$. However, the proportion of van der Waals interactions changes from I to II. The share of $\mathrm{H} \cdots \mathrm{H}$ decreases, while the share of $\mathrm{C} \cdots \mathrm{H} / \mathrm{H} \cdots \mathrm{C}$, on the contrary, increases. The proportion of contacts of the $\mathrm{C} \cdots \mathrm{Cl} / \mathrm{Cl} \cdots \mathrm{C}$ type decreases, which in compound I is explained by the presence of the anion- $\pi$ interaction. The replacement of the anion leads to an increase in the proportion of $\mathrm{H} \cdots \mathrm{Hal} / \mathrm{Hal} \cdots \mathrm{H}$ and $\mathrm{O} \cdots \mathrm{H} / \mathrm{H} \cdots \mathrm{O}$ contacts in the cation in compound III compared to I and II.

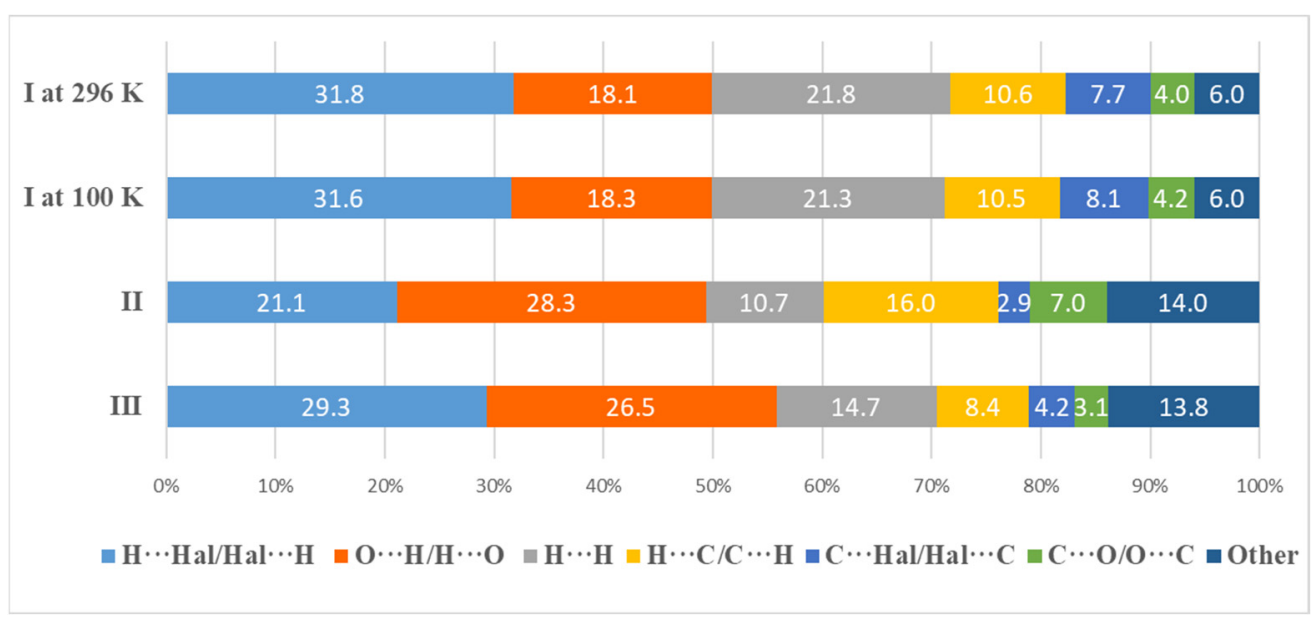

Figure 7. Percentage contributions to the Hirshfeld surface area for the various close intermolecular contacts for cations in I-III.

In the anions in compound $\mathbf{I}$, a temperature change also does not affect the fraction of intermolecular interactions (Figure 8). In the transition from I to II in anions, the proportion of hydrogen bonds in the total increases. In II, the ratio of $\mathrm{C} \cdots \mathrm{Cl} / \mathrm{Cl} \cdots \mathrm{C}$ and $\mathrm{Cl} \cdots \mathrm{Cl}$ interactions strongly decreases, which, as noted above, is due to the absence of anion $-\pi$ interaction and halogen bonds in II. The replacement of a chlorine atom by fluorine leads to an increase in the proportion $\mathrm{H} \cdots \mathrm{Hal} / \mathrm{Hal} \cdots \mathrm{H}$, which may not all be called hydrogen bonds [52], but the virtual absence of other types of interactions. This may be because fluorine is not characterized by the formation of both hydrogen bonds and different types of non-valent interactions.

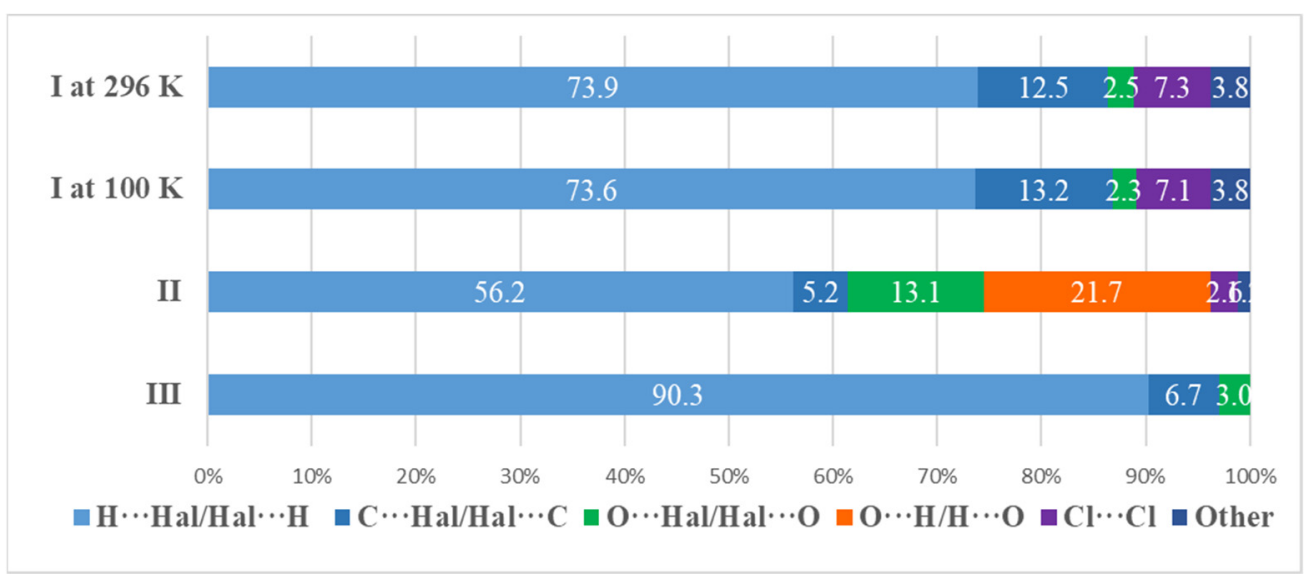

Figure 8. Percentage contributions to the Hirshfeld surface area for the various close intermolecular contacts for anions in I-III.

\section{Conclusions}

Although the compounds are similar (the same cation and octahedral or pseudooctahedral anion) and crystallize in the same space group, the compounds are not isostructural. They form a different system of hydrogen bonds and packing. For the first time, uranium 
and platinum compounds with protonated nicotinic acid were obtained, in which there are no M-N or M-O coordination bonds. These compounds are stabilized by classical hydrogen bonds of the $\mathrm{N}-\mathrm{H} \cdots \mathrm{Cl} / \mathrm{O}$ and $\mathrm{O}-\mathrm{H} \cdots \mathrm{Cl} / \mathrm{O}$ types, as well as by nonclassical $\mathrm{C}-\mathrm{H} \cdots \mathrm{Cl}$ hydrogen bonds, halogen bonds, and $\pi$-anionic interactions in $(\mathrm{HNic})_{2}\left[\mathrm{PtCl}_{6}\right]$. In $(\mathrm{HNic})_{2}\left[\mathrm{UO}_{2} \mathrm{Cl}_{4}\right]$, the structure is stabilized by $\mathrm{N}-\mathrm{H} \cdots \mathrm{Cl} / \mathrm{O}$ and $\mathrm{O}-\mathrm{H} \cdots \mathrm{Cl} / \mathrm{O}$ hydrogen bonds. Replacement of the anion in $(\mathrm{HNic})_{2}\left[\mathrm{SiF}_{6}\right]$ leads to the formation of another type of packing.

Supplementary Materials: The following are available online at https: / www.mdpi.com/article/ 10.3390 / cryst12020271/s1, Figure S1. Experimental and theoretical powder XRD spectra of I at 296 K. Figure S2. The 2D fingerprint plots of interatomic interactions for cation in I at $100 \mathrm{~K}$ show the percentages of contacts contributed to the total Hirshfeld surface area of the molecules. Figure S3. The $2 \mathrm{D}$ fingerprint plots of interatomic interactions for cation in II at $100 \mathrm{~K}$ show the percentages of contacts contributed to the total Hirshfeld surface area of the molecules. Figure S4. The 2D fingerprint plots of interatomic interactions for cation in III at $100 \mathrm{~K}$ show the percentages of contacts contributed to the total Hirshfeld surface area of the molecules. Figure S5. The 2D fingerprint plots of interatomic interactions for anion in I at $100 \mathrm{~K}$ show the percentages of contacts contributed to the total Hirshfeld surface area of the molecules. Figure S6. The 2D fingerprint plots of interatomic interactions for anion in II at $100 \mathrm{~K}$ show the percentages of contacts contributed to the total Hirshfeld surface area of the molecules. Figure S7. The 2D fingerprint plots of interatomic interactions for anion in III at $100 \mathrm{~K}$ show the percentages of contacts contributed to the total Hirshfeld surface area of the molecules. Table S1. Bond lengths for I at $100 \mathrm{~K}$. Table S2. Bond angles for I at $100 \mathrm{~K}$. Table S3. Torsion angles for I at $100 \mathrm{~K}$. Table S4. Bond lengths for I at 296 K. Table S5. Bond angles for I at 296 K. Table S6. Hydrogen bonds for I at 296 K. Table S7. Torsion angles for I at $296 \mathrm{~K}$. Table S8. Bond lengths for II at $100 \mathrm{~K}$. Table S9. Bond angles for II at $100 \mathrm{~K}$. Table S10. Torsion angles for II at $100 \mathrm{~K}$.

Author Contributions: Contributions: conceptualization, M.S.G. and A.V.S.; methodology, M.A.V., A.P.N.; validation, M.S.G.; investigation, M.A.V., A.P.N., A.V.S., M.S.G.; writing-original draft preparation, A.P.N., A.V.S., M.S.G.; writing—review and editing, A.P.N., A.V.S. visualization, A.P.N.; supervision, M.S.G.; project administration, M.S.G. All authors have read and agreed to the published version of the manuscript.

Funding: The study was supported by the Ministry of Science and Higher Education of the Russian Federation (program no. 122011300061-3).

Acknowledgments: X-ray diffraction experiments were performed at the Center for Shared Use of Physical Methods of Investigation at the Frumkin Institute of Physical Chemistry and Electrochemistry, RAS.

Conflicts of Interest: The authors declare no conflict of interest.

\section{References}

1. Nicotinic Acid I C5H4NCOOH-PubChem. Available online: https://pubchem.ncbi.nlm.nih.gov/compound/Nicotinic-acid (accessed on 29 January 2022).

2. Mahmudov, K.T.; Kopylovich, M.N.; Guedes da Silva, M.F.C.; Pombeiro, A.J.L. Non-covalent interactions in the synthesis of coordination compounds: Recent advances. Coord. Chem. Rev. 2017, 345, 54-72. [CrossRef]

3. Lucas, X.; Bauzá, A.; Frontera, A.; Quiñonero, D. A thorough anion $-\pi$ interaction study in biomolecules: On the importance of cooperativity effects. Chem. Sci. 2016, 7, 1038-1050. [CrossRef] [PubMed]

4. Lu, W.; Chan, M.C.W.; Zhu, N.; Che, C.M.; He, Z.; Wong, K.Y. Structural Basis for Vapoluminescent Organoplatinum Materials Derived from Noncovalent Interactions as Recognition Components. Chem. A Eur. J. 2003, 9, 6155-6166. [CrossRef] [PubMed]

5. Zhuang, W.R.; Wang, Y.; Cui, P.F.; Xing, L.; Lee, J.; Kim, D.; Jiang, H.L.; Oh, Y.K. Applications of $\pi-\pi$ stacking interactions in the design of drug-delivery systems. J. Control. Release 2019, 294, 311-326. [CrossRef]

6. Dudenko, D.V.; Yates, J.R.; Harris, K.D.M.; Brown, S.P. An NMR crystallography DFT-D approach to analyse the role of intermolecular hydrogen bonding and $\pi-\pi$ interactions in driving cocrystallisation of indomethacin and nicotinamide. CrystEngComm 2013, 15, 8797-8807. [CrossRef]

7. Svenson, J.; Karlsson, J.G.; Nicholls, I.A. 1H Nuclear magnetic resonance study of the molecular imprinting of (-)-nicotine: Template self-association, a molecular basis for cooperative ligand binding. J. Chromatogr. A 2004, 1024, 39-44. [CrossRef]

8. Gokula, R.P.; Mahato, J.; Tripathi, A.; Singh, H.B.; Chowdhury, A. Self-Assembly of Nicotinic Acid-Conjugated Selenopeptides into Mesotubes. ACS Appl. Bio. Mater. 2021, 4, 1912-1919. [CrossRef] 
9. Trzesowska-Kruszynska, A. On construction of lead coordination polymers derived from $\mathrm{N}^{\prime}$-(2-hydroxybenzylidene)nicotinohyd razide via covalent and non-covalent interactions. J. Coord. Chem. 2014, 67, 120-135. [CrossRef]

10. Lu, J.; Zhao, K.; Fang, Q.R.; Xu, J.Q.; Yu, J.H.; Zhang, X.; Bie, H.Y.; Wang, T.G. Synthesis and characterization of four novel supramolecular compounds based on metal zinc and cadmium. Cryst. Growth Des. 2005, 5, 1091-1098. [CrossRef]

11. Gianneschi, N.C.; Tiekink, E.R.T.; Rendina, L.M. Dinuclear platinum complexes with hydrogen-bonding functionality: Noncovalent assembly of nanoscale cyclic arrays. J. Am. Chem. Soc. 2000, 122, 8474-8479. [CrossRef]

12. Pahade, P.; Katolkar, P. A systematic review on metal complexes of some medicinal compounds. Int. J. Appl. Adv. Sci. Res. 2020, 5 , 9-21. [CrossRef]

13. Fong, C.W. Platinum anti-cancer drugs: Free radical mechanism of Pt-DNA adduct formation and anti-neoplastic effect. Free Radic. Biol. Med. 2016, 95, 216-229. [CrossRef]

14. Cohen, G.L.; Ledner, J.A.; Bauer, W.R.; Ushay, H.M.; Caravana, C.; Lippard, S.J. Sequence dependent binding of cisdichlorodiammineplatinum(II) to DNA. J. Am. Chem. Soc. 1980, 102, 2487-2488. [CrossRef]

15. Crisp, M.G.; Pyke, S.M.; Rendina, L.M. Dinuclear organoplatinum(II)-methyldiphenylphosphine complexes of nicotinic acid. J. Organomet. Chem. 2000, 607, 222-226. [CrossRef]

16. Fedorov, B.S.; Fadeev, M.A.; Kozub, G.I.; Aldoshin, S.M.; Aliev, Z.G.; Atovmyan, L.O.; Konovalova, N.P.; Sashenkova, T.E.; Kondrat'Eva, T.A.; Blokhina, S.V. Synthesis and antimetastatic activity of metal complexes based on substituted pyridinecarboxylic acid amides and platinum tetrachloride. Pharm. Chem. J. 2009, 43, 134-138. [CrossRef]

17. Durbin, P.W.; Kullgren, B.; Ebbe, S.N.; Xu, J.; Raymond, K.N. Chelating agents for uranium(vi): 2. Efficacy and toxicity of tetradentate catecholate and hydroxypyridinonate ligands in mice. Health Phys. 2000, 78, 511-521. [CrossRef] [PubMed]

18. Safonov, A.V.; Perepelov, A.V.; Babich, T.L.; Popova, N.M.; Grouzdev, D.S.; Filatov, A.V.; Shashkov, A.S.; Demina, L.I.; Nazina, T.N. Structure and gene cluster of the O-polysaccharide from Pseudomonas veronii A-6-5 and its uranium bonding. Int. J. Biol. Macromol. 2020, 165, 2197-2204. [CrossRef] [PubMed]

19. Raditzky, B.; Schmeide, K.; Sachs, S.; Geipel, G.; Bernhard, G. Interaction of uranium(VI) with nitrogen containing model ligands studied by laser-induced fluorescence spectroscopy. Polyhedron 2010, 29, 620-626. [CrossRef]

20. Joseph, C.; Raditzky, B.; Schmeide, K.; Geipel, G.; Bernhard, G. Complexation of uranium by sulfur and nitrogen containing model ligands in aqueous solution. Uranium Min. Hydrogeol. 2008, 2008, 539-548. [CrossRef]

21. Thuéry, P.; Harrowfield, J. Recent advances in structural studies of heterometallic uranyl-containing coordination polymers and polynuclear closed species. Dalt. Trans. 2017, 46, 13660-13667. [CrossRef]

22. Fortier, S.; Hayton, T.W. Oxo ligand functionalization in the uranyl ion (UO22+). Coord. Chem. Rev. 2010, 254, 197-214. [CrossRef]

23. Kannan, S.; Kumar, M.; Sadhu, B.; Jaccob, M.; Sundararajan, M. Unusual intramolecular CH . . O hydrogen bonding interaction between a sterically bulky amide and uranyl oxygen. Dalt. Trans. 2017, 46, 16939-16946. [CrossRef] [PubMed]

24. Carter, K.P.; Kalaj, M.; Cahill, C.L. Harnessing uranyl oxo atoms via halogen bonding interactions in molecular uranyl materials featuring 2,5-diiodobenzoic acid and N-donor capping ligands. Inorg. Chem. Front. 2017, 4, 65-78. [CrossRef]

25. Andrews, M.B.; Cahill, C.L. Utilizing hydrogen bonds and halogen-halogen interactions in the design of uranyl hybrid materials. Dalt. Trans. 2012, 41, 3911-3914. [CrossRef]

26. Natrajan, L.S. Developments in the photophysics and photochemistry of actinide ions and their coordination compounds. Coord. Chem. Rev. 2012, 256, 1583-1603. [CrossRef]

27. Baldoví, J.J.; Cardona-Serra, S.; Clemente-Juan, J.M.; Coronado, E.; Gaita-Ariño, A. Modeling the properties of uranium-based single ion magnets. Chem. Sci. 2013, 4, 938-946. [CrossRef]

28. Fox, A.R.; Bart, S.C.; Meyer, K.; Cummins, C.C. Towards uranium catalysts. Nature 2008, 455, 341-349. [CrossRef]

29. Arnold, P.L. Uranium-mediated activation of small molecules. Chem. Commun. 2011, 47, 9005-9010. [CrossRef]

30. SAINT-Plus; Version 7.68; Shuker AXS Inc.: Madison, WI, USA, 2012.

31. Sheldrick, G.M. SADABS; Bruker AXS: Madison, WI, USA, 2008.

32. Sheldrick, G.M. A short history of SHELX. Acta Crystallogr. Sect. A Found. Crystallogr. 2008, 64, 112-122. [CrossRef]

33. Sheldrick, G.M. Crystal structure refinement with SHELXL. Acta Crystallogr. Sect. C Struct. Chem. 2015, 71, 3-8. [CrossRef]

34. Dolomanov, O.V.; Bourhis, L.J.; Gildea, R.J.; Howard, J.A.K.; Puschmann, H. OLEX2: A complete structure solution, refinement and analysis program. J. Appl. Crystallogr. 2009, 42, 339-341. [CrossRef]

35. Groom, C.R.; Bruno, I.J.; Lightfoot, M.P.; Ward, S.C. The Cambridge Structural Database. Acta Crystallogr. Sect. B Struct. Sci. Cryst. Eng. Mater. 2016, 72, 171-179. [CrossRef] [PubMed]

36. Liu, M.; Yin, C.; Chen, P.; Zhang, M.; Parkin, S.; Zhou, P.; Li, T.; Yu, F.; Long, S. sp2CH. ․ Cl hydrogen bond in the conformational polymorphism of 4-chloro-phenylanthranilic acid. CrystEngComm 2017, 19, 4345-4354. [CrossRef]

37. Aakeröy, C.B.; Evans, T.A.; Seddon, K.R.; Pálinkó, I. The C-H $\cdots \mathrm{Cl}$ hydrogen bond: Does it exist? New J. Chem. 1999, 23, 145-152. [CrossRef]

38. Novikov, A.P.; Ryagin, S.N.; Grigoriev, M.S.; Safonov, A.V.; German, K.E. 5,5-Dichloro-6-hydroxydihydropyrimidine-2,4(1H,3H)dione: Molecular and crystal structure, Hirshfeld surface analysis and the new route for synthesis with $\mathrm{Mg}(\operatorname{ReO} 4) 2$ as a new catalyst. Acta Crystallogr. Sect. E Crystallogr. Commun. 2020, 76, 1557-1561. [CrossRef] [PubMed]

39. Gel'mbol'dt, V.O.; Minacheva, L.K.; Ganin, E.V.; Sergienko, V.S. Crystal structure of bis(3-carboxypyridinium) hexafluorosilicate. Russ. J. Inorg. Chem. 2008, 53, 875-878. [CrossRef] 
40. Macazaga, M.J.; Rodríguez, J.; Quiroga, A.G.; Peregina, S.; Carnero, A.; Navarro-Ranninger, C.; Medina, R.M. Platinum(IV) complexes of 3- and 4-picolinic acids containing ammine or isopropylamine ligands-Synthesis, characterization, x-ray structures, and evaluation of their cytotoxic activity against cancer cell lines. Eur. J. Inorg. Chem. 2008, 2008, 4762-4769. [CrossRef]

41. Medina, R.M.; Rodríguez, J.; Quiroga, A.G.; Ramos-Lima, F.J.; Moneo, V.; Carnero, A.; Navarro-Ranninger, C.; Macazaga, M.J. Influence of (Hydroxymethyl)pyridine and Pyridine-carboxylic Acids, in trans-Position to the Isopropylamine and Ammine Ligands, on the Cytotoxicity of Platinum Complexes. Chem. Biodivers. 2008, 5, 2090-2100. [CrossRef]

42. Mit'kovskaya, E.V.; Mikhailov, Y.N.; Gorbunova, Y.; Serezhkina, L.; Serezhkin, V. X-ray diffraction study of [UO2SO4\{NH 2CON(CH3)2\}2]. Russ. J. Inorg. Chem. 2004, 49, 1923-1927.

43. Spackman, M.A.; Jayatilaka, D. Hirshfeld surface analysis. CrystEngComm 2009, 11, 19-32. [CrossRef]

44. Piña, J.J.; Gil, D.M.; Pérez, H. Revealing new non-covalent interactions in polymorphs and hydrates of Acyclovir: Hirshfeld surface analysis, NCI plots and energetic calculations. Comput. Theor. Chem. 2021, 1197, 113133. [CrossRef]

45. Marek, P.H.; Urban, M.; Madura, I.D. The study of interactions with a halogen atom: Influence of NH2 group insertion on the crystal structures of meta-bromonitrobenzene derivatives. Acta Crystallogr. Sect. C Struct. Chem. 2018, 74, 1509-1517. [CrossRef] [PubMed]

46. Novikov, A.P.; Bezdomnikov, A.A.; Grigoriev, M.S.; German, K.E. Synthesis, crystal structure and Hirshfeld surface analysis of 2-(perfluorophenyl)acetamide in comparison with some related compounds. Acta Crystallogr. Sect. E Crystallogr. Commun. 2022, 78, 80-83. [CrossRef]

47. Psycharis, V.; Dermitzaki, D.; Raptopoulou, C.P. The Use of Hirshfeld Surface Analysis Tools to Study the Intermolecular Interactions in Single Molecule Magnets. Crystals 2021, 11, 1246. [CrossRef]

48. Tan, S.L.; Jotani, M.M.; Tiekink, E.R.T. Utilizing Hirshfeld surface calculations, non-covalent inter-action (NCI) plots and the calculation of inter-action energies in the analysis of mol-ecular packing. Acta Crystallogr. Sect. E Crystallogr. Commun. 2019, 75, 308-318. [CrossRef]

49. Spackman, P.R.; Turner, M.J.; McKinnon, J.J.; Wolff, S.K.; Grimwood, D.J.; Jayatilaka, D.; Spackman, M.A. CrystalExplorer: A program for Hirshfeld surface analysis, visualization and quantitative analysis of molecular crystals. J. Appl. Crystallogr. 2021, 54, 1006-1011. [CrossRef]

50. Novikov, A.P.; Volkov, M.A.; Safonov, A.V.; Grigoriev, M.S.; Abkhalimov, E.V. Synthesis and Characterization of New Guanine Complexes of Pt(IV) and Pd(II) by X-Ray Diffraction and Hirshfeld Surface Analysis. Crystals 2021, 11, 1417. [CrossRef]

51. Savastano, M.; García, C.; López de la Torre, M.D.; Pichierri, F.; Bazzicalupi, C.; Bianchi, A.; Melguizo, M. Interplay between salt bridge, hydrogen bond and anion- $\pi$ interactions in thiocyanate binding. Inorganica Chim. Acta 2018, 470, 133-138. [CrossRef]

52. Howard, J.A.K.; Hoy, V.J.; O'Hagan, D.; Smith, G.T. How good is fluorine as a hydrogen bond acceptor? Tetrahedron 1996, 52, 12613-12622. [CrossRef] 